\title{
Problem based Learning Model assisted Edmodo
}

\author{
D. Setiawati \\ Universitas Negeri Surabaya \\ Surabaya, Indonesia
}

\author{
N. Nasution \\ Universitas Negeri Surabaya \\ Surabaya, Indonesia
}

\author{
I. Basuki \\ Universitas Negeri Surabaya \\ Surabaya, Indonesia
}

\begin{abstract}
The purpose of this study is to improve the competence of learners' knowledge in social studies by applying problem-based learning model that assisted Edmodo on webbased learning. This research used a quantitative experimental research with pre-test group design and post-test control. The sample group consisted of seventy-two students with random sampling technique. The result of the analysis shows that there is a significant difference between the competence of the students' knowledge which is taught using Problem Based Learning with Edmodo (PBLAE) with problem-based leaning assisted by picture (PBLAP).
\end{abstract}

\section{Keywords-Model Assisted Edmodo}

\section{INTRODUCTION}

In the 2013, the core curriculum of all subjects consists of four competencies. The core competency formulation includes of spiritual attitude, social attitude competence, knowledge competence, and skill competence. The decline of the national examination score in 2017 became the primary reason of this research. In which, this research focused on increasing the knowledge competence according to government instruction on Permendikbud 103 year 2014 that learning using interactive model, inspiration, fun, challenging, and motivate the students to participate actively.

Learning models need to be balanced with the media that will allow students to understand the material to be conveyed by teachers [4, 15]. With the development of increasingly sophisticated and concise media, teachers can use information and communication media more varied. Information processing and distribution through telecommunication network opens many opportunities to be utilized in the field of education. Therefore, web-based learning is considered attractive to be applied in the education system in today's globalization era [2]. Furthermore, examining internal validity and external validity of web-based learning was in accordance with the theory of Instruction Design and students who studied with the web has high competence [3]. Virtual learning has been suggested for improvement to improve the quality of education [14].
The learning model continues to grow as an effort to improve the quality of education and the quality of learning. The ability of teachers in designing learning that is able to optimize student learning outcomes is the key to the achievement of learning objectives. Effective and efficient learning models use real world problems to emphasize student activity in the learning process, including problem-based learning (PBL) $[6,17]$. PBL is an effective learning model that hone learning skills to master a number of material so that it can be remembered for a long time and can be revealed at a certain time [17].

Online learning provides high opportunities for students to interact with peers and teachers [9]. PBLs implemented in virtual learning have been shown to increase the ability to solve problems.

Virtual learning is conducted by utilizing media that can stimulate students to learn and get answers to the questions sought [12]. A study has developed a web-based learning model based on constructivist theory, collaborative learning techniques and principles of instructional design can be well tolerated by students treated [2].

Edmodo is a web-based medium [7, 11]. Edmodo is a secure learning network used to manage communication between students, teachers, and parents anytime and anywhere while connected to the internet [1]. Edmodo is rated as a medium that fits the current digital age [8]. Social networking forums are able to become a bridge between formal and informal education so that students' learning environment becomes widespread. The Edmodo feature allows students to interact with their subject matter, peers, and facilitators [16].

There has been research that develops PBL learning models integrated with virtual learning for undergraduate students in the Photography for Communication Arts course. Virtual learning is applied using multiple media. The analysis prove that the model is able to encourage students to work together in solving problems [12]. Based on the previous research, the purpose of this research focuses on certain 
media, that is to test the model of Edmodo-assisted PBL and image-assisted PBL, which of them provides optimal learning outcomes.

\section{METHOD}

This research is a quantitative type of quasi experiments with pretest design and posttest control group designs listed in table I.

TABLE I. RESEARCH DESIGN

\begin{tabular}{|c|c|c|c|}
\hline Class & Pre-test & Perlakuan & Post-test \\
\hline Experiment & $\mathrm{O}^{\mathrm{a}}$ & $\mathrm{X}^{\mathrm{e}}$ & $\mathrm{O} 2^{\mathrm{b}}$ \\
\hline Control & $\mathrm{O} 3^{\mathrm{c}}$ & $Y^{f}$ & $\mathrm{O} 4^{\mathrm{d}}$ \\
\hline & & & $\begin{array}{r}{ }^{\text {a. }} \text { Pre-test control class } \\
\text { b. Post-test control class } \\
{ }^{\text {c. }} \text { Pre-test experiment class } \\
\text { d. Post-test experiment class } \\
\text { e. PBLAE model } \\
\text { f. } \text { PBLAP model }\end{array}$ \\
\hline
\end{tabular}

The research variables include independent variability of PBLAE learning model that is applied to the experimental class and PBLAP learning model applied to the control class. Table 2. Formulation of learning objectives.

\section{$(1,2,3,4,5,6,7,8$ is an indicator of competence of knowledge)}

From Table 2 it can be seen that eight achievement indicators of knowledge competence have high order thinking skill form. The goals of the student are specifically formulated and representative by taking into account the Audience Behavior Conditions Degree (ABCD). The sampling technique used random sampling. Randomization is done on the target population of five classes that all have an android based mobile phone. Teachers and students have sufficient tools to upload content from the internet [14]. From the five to the weld there are two classes, one class as the control class and the other as the experimental class. The sample consisted of learners whose average age was 17 years with details of 17 men and 20 women in the control class, 19 men and 16 women in the experimental class.

Instruments consist of syllabus, Study Plan of PBLAE, Lesson Plan of Learning PBLAE, Student Worksheet 1, Student Worksheet 2. In all instruments, faculty validity and construct validity are determined by feasibility study by examiner. The data analysis used as the collection data shows a valid and reliable result.

The implementation of learning activities in control class and experiment class were for two meetings. Each meeting is ninety minutes. Each class applies PBL learning syntax, which differentiates was in the experimental class utilizing Edmodo features, while in the learning control class used the offline image media. In the experimental class, the computer used the school provided during face-to-face learning, and then students use their own mobile phone outside the face-to-face class.

\section{RESULTS AND DISCUSSION}

The data generated from pretest before students are treated and posttest after the treatment. The average of the pretest and posttest results is shown in Table III:

TABle II. The AVERAnge of Pre-Test And Post-Test

\begin{tabular}{ccccc}
\hline Test & $\begin{array}{c}\text { Learning } \\
\text { Model }\end{array}$ & Mean & $\begin{array}{c}\text { Std. } \\
\text { Deviation }\end{array}$ & $\mathrm{N}$ \\
\hline \multirow{3}{*}{ Pretest } & PBLAE & 29.5429 & 4.65481 & 35 \\
& PBLAP & 30.1081 & 5.48120 & 37 \\
& Total & 29.8333 & 5.06854 & 72 \\
Posttest & PBLAE & 69.0286 & 9.22428 & 35 \\
& PBLAP & 58.5135 & 9.13668 & 37 \\
& Total & 63.6250 & 10.53958 & 72 \\
Total & PBLAE & 49.2857 & 21.16679 & 70 \\
& PBLAP & 44.3108 & 16.13889 & 74 \\
& Total & 46.7292 & 18.85136 & 144 \\
\hline
\end{tabular}

Table III shows that basic learning abilities treated with PBLAE and PBLAG tend to be the same. Furthermore, comparing the average pretest and posttest can be seen that there is progress of competence after being treated in each class, the posttest PBLAE value shows higher number.

TABLE III. BASIC LEARNING ABILITIES

\begin{tabular}{|c|c|c|c|c|c|c|}
\hline \multirow{2}{*}{$\begin{array}{l}\text { Knowledge's } \\
\text { dimension }\end{array}$} & \multicolumn{4}{|c|}{ Cognitive dimension } & \multirow[b]{2}{*}{ C5 } & \multirow[b]{2}{*}{ C6 } \\
\hline & $\overline{\mathrm{C} 1}$ & -2 & $\mathrm{C} 3$ & $\mathrm{C} 4$ & & \\
\hline \multicolumn{7}{|l|}{ Factual } \\
\hline Conceptual & & & & 1 & 7 & 2 \\
\hline Procedural & & & & 5 & 3,4 & \\
\hline Metacognitive & & & & & 6 & 8 \\
\hline
\end{tabular}

The increasing value of pretest to posttest is the influence of the learning model on the knowledge competence, which through the technique of controlling the learner has never received in the previous treatment. Differences in competence are also caused by the utilization of edmodo can give in doing the absorption of teaching materials at the time and the most appropriate place. There is a material absorption by the learner which the learner experiences a process of assimilation. The simultaneously undergoes accommodation by reconstructing the structure of the mind has gained new information.

Assimilation and accommodation occur sustainably not limited to the amount of time at face-to-face, but non-face-toface exchange and information take place until learners reach a mental structure that illustrates a variety of reasons by continuing to search for problem-solving and finding reasons by using the problem solving. By the time they find a problem solving, the learners have reached equilibration.

The process of assimilation occurs when the learners are given activities on the student worksheet 1 , and the accomodation occurs when the learners are given activities on Worksheet 2. Next there is equilibration seen at the time of posttest. 
From the available data is done prerequisite test and analyzed. The prescription test shows that the data comes from a normally distributed population.

TABle IV. NORMAlities OF Distribution TeST

\begin{tabular}{|c|c|c|}
\hline \multirow{2}{*}{ Normal Parameters ${ }^{\mathrm{a}, \mathrm{b}}$} & Mean & 51.8264 \\
\hline & Std. Deviation & 15.35242 \\
\hline \multirow{3}{*}{ Most Extreme Differences } & Absolute & 0.092 \\
\hline & Positive & 0.086 \\
\hline & Negative & -0.092 \\
\hline \multicolumn{2}{|c|}{ Kolmogorov-Smirnov Z } & 1.100 \\
\hline \multicolumn{2}{|c|}{ Asymp. Sig. (2-tailed) } & 0.178 \\
\hline \multicolumn{2}{|l|}{$\mathrm{N}$} & 144 \\
\hline
\end{tabular}

The homogeneity test of variance in the Levene's Test table shows the value (Significance) of Sig. 0.090 where> 0.05 so it is concluded that the variant is the same.

TABLE V. TESTS OF BETWEEN-SUBJECTS’ EFFECTS

\begin{tabular}{cccccc}
\hline Source & $\begin{array}{c}\text { Type III } \\
\text { Sum of } \\
\text { Squares }\end{array}$ & df & $\begin{array}{c}\text { Mean } \\
\text { Square }\end{array}$ & F & Sig. \\
\hline $\begin{array}{c}\text { Corrected } \\
\text { Model }\end{array}$ & $20262.561^{\mathrm{a}}$ & 3 & 6754.187 & 70.345 & 0.000 \\
Intercept & 387191.398 & 1 & $\begin{array}{c}387191.3 \\
98\end{array}$ & $\begin{array}{c}4032.6 \\
14\end{array}$ & 0.000 \\
& & & 18287.26 & 190.46 & 0.000 \\
Test & 18287.267 & 1 & 7 & 3 & \\
& & & 421.620 & 4.391 & 0.038 \\
Learning Model & 421.620 & 1 & 1862.601 & 19.399 & 0.000 \\
Test * Learning & 1862.601 & 1 & & & \\
Model & & & & & \\
Error & 13442.099 & 140 & 96.015 & & \\
Total & 420485.000 & 144 & & & \\
Corrected Total & 33704.660 & 143 & & & \\
\hline
\end{tabular}

Table V Shows a significant influence on the competence of students' knowledge competence scores that are treated with PBLAE. There is a significant in-use of the PBLAE model of learning with the PBLAP learning model.

In PBLAE, the learning materials are loaded on edmodo library features. The material used as the object of observation, analyzed, identified and discussed by the students in the group work, the teacher acts as a facilitator. The PBL learning model is characterized by an 'inquiry method' which creates problems to motivate students in investigation [12]. The implementation of the learning undertaken provides the knowledge that can be a benefit because they are facing phenomenon has that become part of the construction undertaken.

The new learning experience is also found in learning PBLAE. The android-based mobile phone has not been used only as a means of communication and download material but also can be used as a learning media. The discussion in the Edmodo group differs from the previous virtual discussion. In the Edmodo group, the discussion was conducted in conjunction with the management of the teacher. Teachers are able to do an intervention whenever needed, where a discussion requires further affirmation and explanation. The discussion also focused only on the material that has been presented. Interesting web-based learning as it has been described becomes the reason for being applied in the education system [2].

The new environment is a group in Edmodo with a pattern of utilization rules presented in its features. These environments give mutual feedback, question and answer, and information. Learning using Edmodo shows the existence of collaboration among students [17, 5]. Discussion occurs during teaching and learning activities in class and outside school hours. Web-based tutoring can be done unlimitedly by distance and students' support to access information and resources as new knowledge $[12,13]$. Sources of up to date information in the students will accelerate students and teachers to develop their knowledge [11].

The process of assimilation occurs when the learners are given activities on the Student Worksheet 1, and the accommodation occurs when the learners are given activities on the Student Worksheet 2. Next is the equilibration seen during the posttest. Deejring found that web-based learning shows the suitability in all aspects of validation and can improve the competence of the learners. In the research implementation of PBLAE also shows an increase in all learners' competence.

A research conducted by Balasubramaniana et al. (2014) is in line with this study which also proves the occurrence of student centers because both show that learners have the opportunity and facilities to be able to build their own knowledge [1]. So, the learners gain profound understanding and ultimately can increase the quality of their competences.

\section{CONCLUSION}

Based on research finding, training should be conducted for teachers to be able to utilize Edmodo in learning as an effort to improve the competence of their learners. The role of parents is also very important in managing the learning time at home.

This research does not utilize the Edmodo feature optimally. It is hoped that further research will utilize the Edmodo feature called parent code to invite parents into the learning group. Utilizing these features is useful to make it easier for parents to monitor the learning activities and the level of learning progress of learners.

\section{REFERENCES}

[1] K. Balasubramaniana, et al., A study on "Student preference towards the use of edmodo as alearning platform to create responsible learning environment", in Procedia - Social and Behavioral Sciences, Vol 144, pp 416-422, 2014

[2] K. Deejring, "The design of web-based learning model using collaborative learning techniques and a scaffolding system to enhance learners' competency in higher education", in Procedia - Social and Behavioral Sciences, Vol 116, pp 436-441, 2014

[3] K. Deejring, "The validation of web-based learning using collaborative learning techniques and a scaffolding system to enhance learners' competency in higher education", in Procedia-Social and Behavioral Sciences, Vol. 174, pp 34-42, 2015 
[4] R. Foster \& D. R. Neal, '12 - Learning social media: student and instructor perspectives", in Social Media for Academics, pp 211-226, 2012

[5] B. Gan et al., "Enhancing students' learning process through interactive digital media: New opportunities for collaborative learning", in Computers in Human Behavior, Vol. 51, pp 652-663, 2015

[6] G. Gorghiu, et al., "Problem-based learning - an efficient learning strategy in the science lessons context", in Procedia-Social and Behavioral Sciences, Vol. 191, pp 1865-1870, 2015

[7] G. Grosseck \& C. Holotescu, "Microblogging multimedia-based teaching methods best practices with Cirip", in Procedia Social and Behavioral Sciences, Vol. 2, pp 2151-2155, 2010

[8] D. G. Krutka et al., "Microblogging about teaching: Nurturing participatory cultures through collaborative online reflection with preservice teachers", in Teaching and Teacher Education, Vol. 40, pp 8393, 2014

[9] J. Mao, "Social media for learning: A mixed methods study on high school students' technology affordances and perspectives", in Computers in Human Behavior, Vol. 33, pp 213-223, 2014

[10] S.N. M. Mohamad et al., Factors affecting lecturers motivation in using online teaching tools. Procedia - Social and Behavioral Sciences, 195, pp 1778 -84, 2015

[11] F. Mohammadi, et al., "What motivates high school teachers to use web-based learning resources for classroom instruction? An exploratory case study in an Iranian smart school". Computers in Human Behavior. 51, pp 373-81, 2015

[12] R. Phungsuk et al., "Development of a problem-based learning model via a virtual learning environment", in Kasetrat journal of social sciences, xxx, pp 1-10, 2017

[13] Y. Song \& S. C. Kong, "Affordances and constraints of BYOD (Bring Your Own Device) for learning and teaching in higher education: Teachers' perspectives", in Internet and Education, Vol. 32, pp 39-46, 2017

[14] A. Strunga, "Using virtual learning communities in shaping the professional identity of primary and preschool pedagogy specialization students: a knowledge management approach", in Procedi -Social and Behavioral Sciences, 18Vol. 0, pp 460-7, 2015

[15] A. Strunga, "The integration of virtual learning communities into universities' knowledge management models", in Procedi-Social and Behavioral Sciences, Vol. 197, pp 2430-2434, 2015

[16] S. G. L. Won et al., "Youth appropriation of social media for collaborative and facilitated design-based learning", in Computers in Human Behavior, Vol. 50, 385-391, 2015

[17] E. H. J. Yew \& K. Goh, "Problem-based learning: An overview of its process and impact on learning", in Health Professions Education, Vol. 2, pp 75-79, 2016. 